\title{
Russian Vision of the EU in its Interactions with the Neighbourhood
}

\author{
Olga Gulyaeva \\ National Centre for Research on Europe, \\ University of Canterbury \\ Kirkwood Village KD04, \\ Christchurch, New Zealand \\ E-mail: olga.gulyaeva@pg.canterbury.ac.nz
}

\begin{abstract}
This article analyses images of the European Union (EU) existing in the discourse of the Russian news media, the general public and the Russian elites. The EU's actions in the countries of Russia's "near neighbourhood" and "far neighbourhood" were among the leading topics, showing high interest in the intensive Russia-EU political relations. The data of this paper comes from a year of monitoring of three daily newspapers, face-to-face interviews with political, business, media and civil society representatives and a public opinion survey. This analysis observed that both partnership and competition exist in Russia-EU political relations.
\end{abstract}

Keywords: EU-Russia relations, external perception, geopolitical space, far neighbourhood, near neighbourhood

\section{Introduction}

The gap between perceptions of each other and the problem of misunderstanding partners still exists in international relations. Gibson (1959, p. 457) defined perception as "the process by which an individual maintains contact with the environment" and discovers information about the world. Knowledge of perceptions is crucial in international relations as "understanding the perceptions and perspectives of the 'other' side can provide a basis for improved communication and give guidance on policy adjustments" (IDEA, 2009, p. 12).

The economic capacity of the European Union (EU) is often considered as fundamental to the EU's superpower status. Bretherton and Vogler (1999, p. 63) argue that " $[\mathrm{t}]$ he growing economic presence of the European Union has ensured 
that in many respects it can be regarded as a great power, rivalling the United States". Indeed, the realisation of the common market has made the EU the largest trading power in the world. In 2010, the EU-27 exported goods, services and foreign direct investment to the amount of 1,349,610 million euros and imported 1,509,092 million euros. At the political level, the EU presents itself as a role model with democratic values, human-orientated policies and coherent agreements. In her article "The European Union's role in global affairs", the EU High Representative Catherine Ashton (2010) concluded that "we in Europe can and should play our part" in order to guarantee global security. The EU emphasises its 'soft' external actions and its preference to reach a consensus rather than to use military power as a problem-solving instrument.

These significant achievements may lead to the EU seeing itself as a political, economic and developmental superpower; however, non-EU countries might reflect on the EU's internal and external profiles quite differently. The issue of how the Russian media, elites and the public perceive the EU's internal and external actions contributes to the understanding of the international position of the EU as a global actor. The main research goal of this analysis is to identify Russian media images of the EU as well as elite and public opinion on the EU within the frame of Russia's relations with its neighbourhood. The term 'near neighbourhood' (or 'near abroad') came into use in the Yeltsin era and comprises the former Soviet space (Adomeit, 2011, p. 1). Russia's far neighbourhood comprises more distant foreign lands. The EU's relations with the post-Soviet space was contextualised in Russia's media through the process of EU enlargement, while the EU's involvement with Russia's far neighbourhood was viewed through the EU's conflict management regarding the Arab Spring.

Russia is of particular importance in determining the EU's external perception for two reasons. First, the eurozone crisis has increased the importance of the emerging BRICS (Brazil, Russia, India, China, and South Africa) economies for the EU. As the EU is Russia's biggest economic partner, Russia has a direct economic interest to provide financial support to the EU. Indeed, at the G-20 summit in 2011, Russia expressed its desire to help in resolving the eurozone crisis. Moreover, Russia has political interest in supporting the EU in this unsettled time. The eurozone crisis has challenged the operation of EU institutions with other regional powers and global actors. In December 2011, thirty-two EU foreign policy experts expressed their concern regarding a damaging effect of the euro crisis on foreign policy. They argued that relations with external global players had been undermined, due to the EU leaders' preoccupation with internal problems (EUobserver, 2011). Arguably, an understanding of the 
opinions of influential BRICS nations towards EU institutions will facilitate a critical interpretation of EU foreign policy actions.

Second, Russia has recently become a member of the Asia-Europe Meeting (ASEM), which assists the EU in establishing less formal economic, political and social relations with Russia. Therefore, Russia is not just a significant economic country within the BRICS, but is also important within the interregional ASEM setting. Whilst Russia is economically close to the EU it is able to maintain a political distance from Europe. For example, Russia did not play a supporting political role in the EU's recent response to the Arab Spring. It has been suggested because Russians share many similar values with the majority of Europeans, this enables Russia's elite to have a constructive view towards the EU's identity (Morini, Peruzzi \& Poletti, 2010, pp. 32-51). Yet at the same time, Russia is also partly in Asia. This allows Russia's political and social communities to keep a distance from the EU and to be critical, yet informed, observers of the ongoing processes of integration occurring in the EU.

Russia's political interactions with the EU occur in two geographical areas. The first is within Russia's "near abroad". Although the European Commission and Council communications have defined EU-Russia relations as a "Strategic Partnership," EU-Russia relations display competition rather than partnership. The crucial reason for this competition is the common European neighbourhood, which is geographically and politically close to both Russia and the EU (Adomeit, 2011, p. 1). The overlap of the EU's positions toward the former USSR states and Russia's foreign policy towards the independent states has challenged EU-Russia contemporary political relations. From Russia's perspective, the fact that EU enlargement moves the EU closer to the Russia's neighbourhood presents a potential threat to Russia's regional interests. As the Russian Foreign Minister noted, the Eastern Partnership is "an attempt to extend the EU's sphere of influence" (Pop, 2009). Russia claims that the territory around its borders composed of former countries of the USSR is Russia's responsibility and is within the ambit of Russia's national interest. As the EU seeks to deepen integration with its eastern neighbours and establish relations with Russia's near neighbourhood it has to engage with Russia (Fischer, 2012). The second area is Russia's "far abroad". Russia's relations with its far neighbourhood are driven by the country's awareness of its limited political abilities on the international arena (Smith, 2007). Russia faces uncertainty over its regional and global role. Arguably, Russia's work on the unification of legislation in accordance to the EU norms and its "modernisation partnership" with the EU were motivated by the country's desire to define itself as a European power. Simultaneously, Russia's refusal to be a partner of ENP can be considered as an attempt by Moscow to 
counteract EU influence and maintain a "great power" status in its affairs with "far neighbours". In particular, Russia has used the conflicts over Abkhazia, South Ossetia, Transnistria and Nagorno-Karabakh as opportunities to compete with the EU, contradict EU principles and demonstrate Russia's relevance (Adomeit, 2011, p. 64). As Secrieru (2010, p. 12) notes, "rather than seeking to merge with the EU, Moscow demands recognition of its own European-ness".

The systematic examination of the EU's visibility in Russia is a growing field of research. Indeed, there is a wide array of literature on the Russian debate about Europe, and latterly the EU, in the frame of Russian state representation (Neumann, 1996). The historical retrospective of Russian perceptions of Europe represents the mainstream of academic research (Lomagin, 2008, pp. 36-40). The research of Secrieru (2010) has covered Russia's perception of the EU in recent times-from 2007 until 2010 — when the global financial crisis and the EU's institutional reforms took place. This study aims both to be a part of the growing literature on EU perceptions in Russia as well as contribute to the ongoing debate in the field by providing unique insights into EU visibility in Russia. This research is based on a comprehensive set of quantitative data. This is the first study of this nature to examine how the EU and its institutions are framed in Russian media over an extended time-frame. Regularity and duration are crucial for this research. This study also examined elite, public and media attitudes towards the EU in the year following the $8^{\text {th }}$ ASEM Summit in Brussels (4-5 October 2010) where Russia was formally accepted into ASEM. This research therefore provides a solid basis for the analysis of this new chapter in Asia-Europe relations through Russia's inclusion in the dialogue between two continents. The novelty of this research is that it offers empirical insight into the EU's visibility from outside of the EU's borders. The crucial questions are how the EU is perceived by the Other, and what are the attitudes of the Other toward the EU's political actions. This research deals with perceptions and is not aiming to identify misperceptions. In other words, this research aims to explore what is an overall picture of the EU's actions from the point of view of Russian media, the public and the elite.

The article begins by outlining the theoretical conceptualisation underpinning perception studies and describing the research design and methods used. A comparative approach was used to cover the perception of the EU in the media, among elites and the general public. The analysis identifies and compares the EU's perceptions across two case studies-Russia's "near neighbourhood" and Russia's "far neighbourhood". The conclusion relates the study's findings to existing academic debate on EU-Russia relations. 


\section{Theoretical conceptualisation}

The issue of self-identification through the understanding of Others has been extensively researched. It is the recognition by Others that constitutes the Self. Cerutti (1992, p. 154) believes that the opposition of 'we' and 'the others' provides emotional ties which are essential for the creation of supranational identity. Greenhill (2008, p. 345) also supports that idea, arguing that "one can only form a sense of one's self through one's social interactions with others". The Other thus become a 'mirror' for the Self used to change/improve the Self. The outcome of the process of recognising the Other is the creation of a collective identity. Despite scholars' concerns about the issue of state identity, there is a lack of research on the importance of the external perceptions in political discourse. This study aims to examine Russia's media coverage of EU affairs. Media acts both as a messenger, reporting political events to the public, and as an influential actor, prioritising certain issues and influencing opinion in the public sphere. The crucial focus of this paper is to examine how media has reported specific EU activities in Russia's near abroad and far abroad. Comparative approach that covers media, general public and elites was adopted.

The theoretical lenses of realism are used in this study to explore EU-Russia relations through the perceptions. The realist paradigm subscribes to self-help and survival (Dunne \& Schmidt, 2005, p. 172) and considers the world in terms of a "competitive realm" in which states employ policies that serve their national interests (Waltz, 1979, p. 127). The rise in influence of Putin, particularly during his second term, significantly encouraged the Russian political elite to develop foreign policy based on the core values of realism (Helén, 2010, p. 16). This realistic view partly explains why the EU is perceived in Russia in zero-sum terms. Moscow considers international politics generally, and its relations with the EU particularly, as a zero-sum game in which the crucial concern is to preserve its interests, sovereignty and territorial integrity (Light, 2008, p. 15). Russia's "divide and rule" approach towards the EU determines Russia's vision of the EU (Helén, 2010, p. 3). The fact that Russia's realist paradigm is in diametric opposition to the EU's institutionalism and multilateralism explains Russia's perceptions of EU actions both in the "common neighbourhood" and in Russia's "far abroad" spaces.

This analysis seeks to examine Russia's vision of the EU in its interactions with the "near neighbourhood" and "far neighbourhood". The main hypothesis is that Russia's perception of the EU takes the form of 'hard power' attributes: military capacities and economic power. The key research questions of this study are as 
follows: (1) What essential features of the EU exist in the media and among the public and elite? (2) What differences in perceptions were observed between the two chosen case-studies? and (3) How did the Russian media, elite and the public evaluate EU actions towards Russia's "near neighbourhood" and "far neighbourhood"?

There is a growing field of research into the issue of external perceptions of the EU. However, research into how these external perceptions influence the EU's own political identity and self-perception are rarer (Fioramonti \& Lucarelli, 2008, p. 193). In addition, the perception of Europe is frequently investigated through the prism of relations between individual European countries; the focus of most research is the perception of the EU institutions by the EU Member States resulting in a rich body of literature which reflect these internal perceptions. For instance, Mir, Dato and Garcia (2010, pp. 35-56) deal with Spanish elites perceptions of the EU and their attitude toward European integration. Another example is the Italian perception of the EU activities (Garcea, 2001, pp. 263268). In addition, there are well-developed studies which explore how the Other perceive the EU and what are the images of the EU outside the Union. Although there are studies which apply cross-national comparison, there are still few studies with "“joined up' approaches" (Statham, 2006, p. 3). In this respect, this research contributes to the field by its methodological nature (media analysis, public opinion survey and elite interviews) and its comparative analyses, which address both media contents and elite and public responses.

\section{Methodology}

The data collection of media images of the EU in Russia's media took place over six months, from 1 January 2011 till 30 June 2011. The study monitored daily four media outlets: three leading newspapers (The Moscow Times, Vedomosti and Rossiyskaya Gazeta) and primetime news bulletin on the television channel (Channel One Russia). Media were selected for their social impact. The Moscow Times, Vedomosti and Rossiyskaya Gazeta are the leading newspapers with the highest national circulation, while Channel One Russia is the highest rated television channel. The media in Russian society has a strong impact, particular since Putin's re-election in 2004, when the mass media, in particular television, "has gradually become the only meaningful vehicle of socialization between rulers and ruled" (Fossato, 2006, p. 4). Circulating 80,000 copies five days a week, Vedomost $i$ is the most reputable Russian business daily newspaper, is orientated 
towards business people and critically thinking recipients who are interested in analytical information and political interpretation. The target audience of the daily English-language newspaper The Moscow Times is primarily foreigners living in Moscow (37\% of readership) and English-speaking Russian readers (63\% of readership). In terms of the social status of readers, mainly specialists (28.5\%) and top managers (28.3\%) are represented (The Moscow Times, 2009). The main readership of the Rossiyskaya Gazeta is "even-tempered adults inclined to conservative views" (Rossiyskaya Gazeta, 2011). Channel One Russia has the largest audience (covering $99.8 \%$ of inhabited territory) and is the federal channel that provides official information on its news broadcasts (Channel One Russia, 2012). During the six months of media monitoring, a total of 551 items that covered the EU and its institutions were found.

The opinions towards EU external activities among Russian elites were drawn from face-to-face interviews conducted between October and December 2011. By the term "elite" we understand people "in position to make decisions having major consequences" (Mills, 1959, p. 4). All the interviews with Russian elites took place in Moscow, where Russian political, social, business and media elites are predominantly concentrated. All interviewees were asked 18 questions and the average duration of the interviews was approximately thirty-five minutes. The questionnaire comprised six sections. The first section canvassed general opinion on the international role of the EU. Second, EU bilateral relations with Russia were explored. The third section addressed opinions on particular economic, political and social issues. The fourth section explored sources of information on the EU. The fifth section contained final questions regarding personal attachment to the EU. In the sixth and final section, respondents were asked to provide three immediate thoughts about the EU. All interviews were in Russian, recorded with the approval of the interviewees, and later transcribed and translated into English. There were 34 interviews conducted with respected and influential Russian elite. This comprised 6 interviews with business representatives, 7 with political representatives, 11 interviews with civil society and 10 with media elites.

The public pillar of this research is based on a survey of 1,002 citizens/ permanent residents of Russia aged 18 and above. The term 'public opinion' refers to shared opinion of individuals on an issue (Yeric \& Todd, 1983, p. 4). Both males and females participated in the survey: 397 males and 605 females. Respondents' occupations were full-time jobs (524 respondents), part-time jobs (81 respondents), self-employed (65 respondents), full-time parent (130 respondents), unemployed (34 respondents), students (66 respondents) and retired (102 respondents). Most of the respondents (94\%) belonged to the 
Russian ethnic group and 5 per cent belonged to Tatar. The majority of interviews took place in Moscow (11\%); however, other regions were also included in the survey: the province of Moscow (4\%), St. Petersburg (5\%), the province of Leningrad (0.1\%), Novosibirsk region (4\%), Nizhny Novgorod region (4\%), Yekaterinburg and the Sverdlovsk region (4\%), Omsk region (2\%), Kazan (4\%), Ufa (3\%), Chelyabinsk region (3\%) and Rostov region (3\%). In order to cover a representative sample of the population, interviewing occurred on weekdays and weekends. The sample size was set at 1,002 respondents, sustaining the margin of error at \pm 2.5 per cent at a confidence level of 95 per cent.

\section{Findings}

\subsection{The EU and Russia's "near abroad"}

Today the EU is engaged in a remarkable integration race, which affects the EU-Russia relationship. Scholars have considered the period following the 2004 enlargement as "a period of depression" (Gomart, 2008, p. 1) and the EU's actions to "freeze its rapprochement with Russia" (Pankov, 2008, p. 173). The crucial reason why Russia expresses strong concerns about enlargement is that EU enlargement is causing remarkable changes in Russia's "backyard", namely the post-Soviet Union space. Enlargement is an attractive way for the EU to increase its influence on Russia's "near-abroad" neighbourhood and has revived the long-standing completion for influence over neighbouring countries.

Reflections on the impact of the EU's political affairs on the post-Soviet Union space were the most visible in the Russian media (Fig. 1). Among the 551 items which referenced the EU and its institutions, there were 100 articles (18\%) with the focus on the EU's relations with its Eastern neighbours. These 100 articles offer an incredibly strong articulation of Russia's government's position towards the EU enlargement as impinging upon Russia's interests in the region. In this respect, the media focused on the EU's future enlargement, particularly on Ukraine's remarkable shift toward the EU. There were seven articles in which EU-Ukrainian politico-economic issues were reported. Russia considers Ukraine's political actions and desire to join the EU and NATO as a direct threat to Russia's imperial political ambitions to regain control over the post-Soviet Union space. Ukraine is faced with the choice to join the Customs Union (with Russia, Kazakhstan and Belarus) or to create a free trade area with the EU. Russian media highlights that these choices are mutually exclusive and that the Ukrainian state's decision will show whether or not Ukraine will get the economic benefits from the ex-Soviet trading bloc, or whether or not Ukraine's 
destiny is to be the "backyard" of the EU. The media promoted the idea that Ukraine would benefit more from forming a coalition with Russia than it would from siding with the EU. Moldova's increasing interest in the EU did not receive the same response as Ukraine's did. One of the possible reasons for Russia's concern about Ukraine is that it is, unlike Moldova, a strategic point for gas transit to the Western Europe and Russia's military presence in Eastern Europe. Another possible reason is that Moldova is geographically separate from Russia, while Ukraine's membership in the EU would shift the border of the EU even closer to Russia. The EU's sanctions against Belarus are regarded by media as an intention to provoke a conflict with Russia and undermine the "Slavic Unity" (Nice, 2012, p. 5).

Figure 1. Proportional distribution of new items reflecting the EU political affairs by region

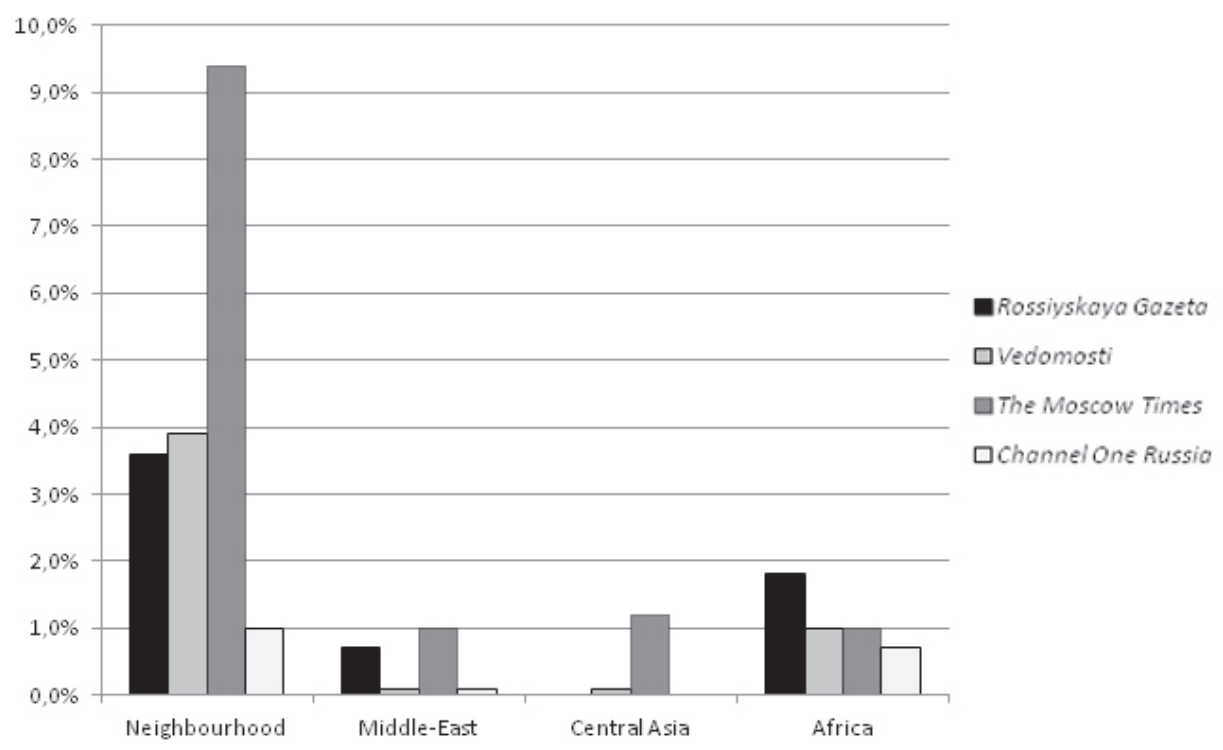

The elites considered the EU's regional affairs through the prism of enlargement. The elites see more risks than opportunities for Russia in the process of the EU enlargement. Elite respondents highlighted the economic, political and social risks of enlargement. Economically, the new EU Member States become more integrated into Western economic processes, and these new economic relationships had a harmful effect on the Russian economy. Economic risks were cited by two business representatives, two political representatives and four civic representatives. Remarkably, only one business representative saw the enlargement in a positive economic light. Politically, enlargement split the EU 
into "Western" and "Eastern" national interests; new Member States of the 2004 enlargement brought greater anxiety about Russia to the EU and raised fears of the Cold War (Leonard \& Popescu, 2007). Three political representatives, five social representatives and one business representative saw political risks in EU enlargement. The EU is getting closer to Russia in geographic terms. Only one business representative considered the enlargement as politically positive for Russia. Socially, the new EU Member States enter into the Schengen Area and introduce a visa barrier to Russian passport holders. Among the Russian elite, five civil society representatives and one business representative have mentioned visa barriers as a social consequence of the EU enlargement. The normative sphere presents considerable opportunities for Russia in the enlargement process. Indeed, if Russia seeks economic-political partnership with the new EU Member States, it has to adopt environmental/technological standards, safety requirements and models of human rights protection. In this respect, civil society saw enormous normative opportunities for Russia in the EU enlargement process, which could encourage Russian policy-makers to assimilate EU norms and practices. There is a fear among political, social and business elites that the EU enlargement brings more negative effects on Russia such as the increasing Russia's politicoeconomic isolation from the rest of Europe. The only advantage for Russia in the EU enlargement lies in the normative dimension of assimilation of EU standards for Russia's further closer work with the EU.

In the frame of EU political action in the post-Soviet Union space, an estimation of the actual importance of the EU to the Russian public was undertaken using a public opinion survey. The EU/Europe was seen as being the most important region. Compared with Asia (excluding China and Japan) and the USA, the EU still remains more important than these two other dominant international players. Surprisingly, Asia, part of which Russia actually belongs to, was primarily seen only as a "somewhat important" actor and the USA, with whom Russia promotes the so-called "reset" in relations, was ranked as "very important" by only 421 (42\%) of respondents. Against the background of the significant politicoeconomic growth of Sino-Russia relations, the fact that China's importance is just 4 per cent lower than the importance of the EU is not surprising. While the Russian media pointed on the EU's competitive relations with Russia on post-Soviet space, the general public highlighted the paramount importance of the EU to Russia. The Russian public do, to some extent, consider the EU as a distinctive political unit, even though the Russian media discusses the EU from the angle of the negative effects of its political actions towards Russia.

This section has presented the most recent snapshot of Russia's perceptions of the EU's actions towards the space of the former USSR. The media depicted the 
EU's enlargement process as an attempt by the EU to increase its influence on the post-Soviet space. In providing various forms of political and developmental support to the former USSR states, the EU is considered to be encroaching on Russia's regional interests. Thus the elites see the EU's foreign policy toward the post-Soviet area as having negative consequences for Russia. In this context, enlargement was seen in a negative light as a political consideration to undermine Russia's regional influence. The public, in contrast, prioritised Russia's relations with the EU, perceiving the EU as the most important region for Russia.

\subsection{The EU and Russia's "far abroad"}

This section deals with the issue of EU actions at Russia's "far abroad"- the EU's participation in the Middle East conflicts. Russia considers the EU's actions in the Middle East to reflect its priority of promoting democracy and human rights ahead of addressing the more urgent economic troubles faced by this region. The EU regards democracy as an ideal system of government, with democracy promotion a core goal of the EU's foreign policy. Some two decades ago, the Treaty on European Union stated that its main objective was "to develop and consolidate democracy and rule of law, and respect for human rights and fundamental freedoms" (European Union, 2012, p. 9). Subsequently, the idea of democracy promotion has been incorporated in further treaties, the 1999 European Initiative for Development and Human in Rights and is put into practice in the 2003 European Neighbourhood Policy and in the TACIS, PHARE and the MEDA programmes. While the discourse of EU normative power is "a particular self of the EU" (Diez \& Manners, 2007, p. 174), external viewers can question the EU's capacities in violent conflicts, where soft dialogue and diplomacy failed. Do external actors believe that the EU as a normative power is capable of resolving or at least managing a violent conflict?

The EU's organised capacity to act in conflicts is questioned in both the Russian media and among elites. Of 34 interviewees, only 3 considered the EU as a leader in the international politics; 17 interviewees replied "no"; 9 answered as "one of the leaders"; 3 answered "depends on the field"; 2 respondents refused to answer. The large number of negative responses reflects the perception of the USA as the undisputed leader. While there was a good degree of confidence in the EU, there was a low respect towards the EU's desire to be an international leader. To the question whether the EU is a great power, 27 interviewees answered "yes," 5 answered "no," and 2 considered the EU as "one of the great powers." For several months in 2011, the Arab Spring was the most covered political event, posing a challenge the EU external performance. 
The Russian media reported this event from a political angle since the EU is the largest Russia's political neighbour. Among all countries involved with the Arab Spring, the EU's interaction with Libya received the largest coverage (21 items), while EU interaction with Tunisia was covered in 4 items, with Egypt in 2, and Syria and Yemen just 1 each. The EU's engagement in these conflicts challenged the credibility of Europe's common foreign policy. Highlighting the lack of single voice and coherence among the EU Member States, the media pictured the EU's external actions as dysfunctional, irrational, unsustainable and rather ineffective. Pro-government media as well as economic and Englishlanguage newspapers emphasised that the EU was engaging in the Arab Spring in concert with the USA. The Rossiyskaya Gazeta claimed that the EU's actions in Libya followed the same mistakes as those made in the Afghan War. The EU's incoherent approach undermined its external actions, and made them weak and inadequate.

The lack of solidarity in the face of international challenges was particularly apparent in the problem of migration flows to the EU, and was highlighted by the media in the context of the Arab Spring. Whenever the media mentioned Tunisia, they focused on the Tunisians that came to Europe by boat. Migration flows from the Arab Spring countries raised growing dissatisfaction among EU citizens with EU governance. This was referred as a "crisis" and inability of the EU to control the wave of asylum migration. Particularly, Channel One represented the EU as a civilised place, occupied by barbarians. Italy and France were victims of the free movement of persons; they could not rely on the support of other EU Member States and had to face the consequences of the Arab Spring in solitude. One commentator depicted the EU as a talking club: "It is talking a lot about the national politics in France, which is less and less similar to France now, but nobody wants to deal with that" (Soshin, 2011). Italy was on the brink of a humanitarian catastrophe, a consequence of asylum; however, "Brussels bureaucrats allowed only sending Catherine Ashton to Tunisia" (Vorobiyov, 2011, p. 8). The sarcastic tone is felt in pro-governmental sources: "Apparently, the EU will turn its attention to the revolutionary refugees only when the whole EU's Mediterranean coast is in a state of emergency" (Vorobiyov, 2011, p. 8). Notably, pro-governmental media were concerned more about the migration flows: seven items, covering illegal immigration to the EU, were found in the Rossiyskaya Gazeta and Channel One and one similar item was found in Vedomosti. The elites, however, did not highlight the case of Arab Spring; however, some interviewees commented that the EU is too gentle with illegal immigrants in granting asylum. A correspondent of RIA-News, for example, claimed that "a person refused a Gypsy to rent an apartment [...], so that this 
Gypsy can sue and receive money that she was refused because she is a Gypsy. These kinds of things Russian elite and population can't understand". The elite survey and media analysis seem to confirm the widely held opinion that the immigration policy of the EU is overly generous.

Together with media and elites, Russian society has questioned the efficiency of the EU (Fig. 2). Among the total of 1,002 of respondents, only 311 (31\%) considered the EU as an efficient actor against $135(13 \%)$ who did not perceive the EU as being efficient with $555(55 \%)$ interviewees not sure. Notably, while the EU's efficiency is questioned, the unity of the EU was perceived strongly: only $99(10 \%)$ did not perceive the EU as a united actor. The majority of respondents (605, or 60\%) saw the EU as being united. An influential Member of the Public Chamber of Russia, Svanidze (2011), also shared an opinion that the $\mathrm{EU}$ is perceived in Russian society as a single union. Regarding the peacefulness of the EU, there were $420(42 \%)$ who considered the EU a peaceful actor, 450 $(45 \%)$ were not sure, while $129(13 \%)$ did not see the EU as a peaceful actor. Notably, there were only $178(18 \%)$ who saw the EU as aggressive and 366 (36\%) who did not consider the EU as aggressive.

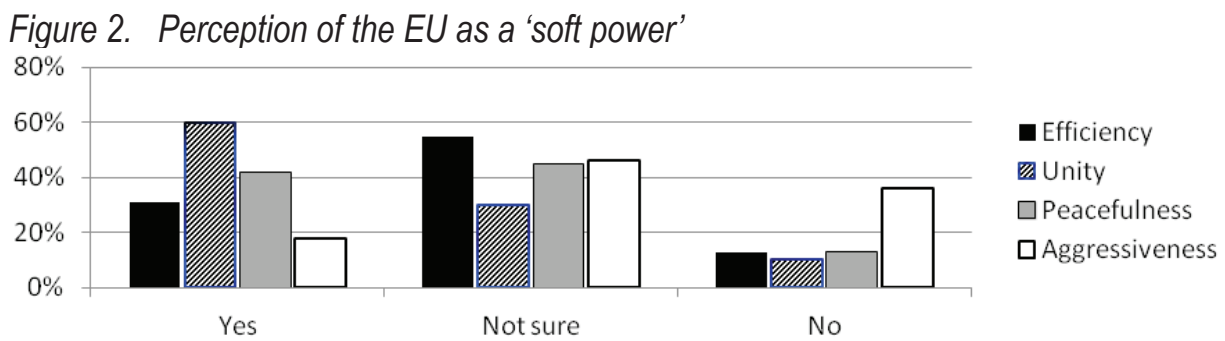

The EU's involvement in the Middle East, encompassing the Israeli-Palestinian Conflict, Iran and Arab Spring events raised concern in the Russian public sphere. Specifically, the public anticipate these conflicts to have a big impact on Russia in the next ten years. Almost 50 per cent of respondents (497) thought the impact would be "huge" on Russia; 298 (30\%) characterised this impact as "significant" while just 206 (21\%) believed that this impact would be small.

The relatively high visibility of the EU's political affairs in the Middle East region is a consequence of the time period in which this media data was conducted. In the first six months of 2011, the EU engaged in a number of activities aimed at achieving conflict resolution in Libya, Syria and Tunisia. The study showed that the media questioned the EU's ambitious goal to achieve a significant success in resolving these conflicts. Apparently, EU 'soft power' was not portrayed in media as an efficient instrument to deal with military and long- 
drawn-out conflicts. Meanwhile, a lack of solidarity within the EU results in the EU failing to face the social consequences of conflicts - migration.

\section{Discussion}

Russia's perceptions of the EU's political affairs are influenced in many ways through its multi-faced relations with its largest neighbour. To Russia, Europe is a model of individual freedom, social norms and values. In this respect, the European Union is an example of economic modernisation, economic dynamism and development (Gerrits, 2008, p. 6). Yet, at the same time, EU-Russia political relations are characterised by the antagonism typical of great power relations and contextualised by an understanding of Russia as being in Europe, but not of Europe. For Russia, Europe is both charming and frightening, appealing and repellent, the antagonist and the protagonist.

This paradox of partnership and competition is interesting. On the one hand, the media speaks of creating a partnership and co-operation between Russia and the EU. The general public together with elites accept the influential economic and political role of the EU on Russia and prioritise economic co-operation with Europe. On the other hand, the media underlines Russia's opposition to the EU's interests. The interviewees from the general public also share the opinion that Russia should be neither closer to the EU, nor to China, Japan, the USA. The idea that Russia and the EU are competitors was expressed by five political, five social and three media elite representatives. This is resolved by a clear differentiation between political and economic interests. Politically, Russia competes with the EU for regional influence and hinders the EU Eastern enlargement. Economically, Russia and the EU are united by common interests. Arguably, Russia stands on the crossroads and must choose either to deal with the $\mathrm{EU}$ as a partner or to be an opponent of the EU. This research has demonstrated that Russia seeks to be recognised as a European nation, while at the same time struggling to be independent of the EU, which it sees as a weak actor.

These surveys and collected media data present a snapshot which allows conclusions about perceptions of the EU's actions to be drawn. Despite the limitations of the methods of data collection, at least two major conclusions can be made. First, the EU is highly important for Russia's media and social discourses. In media and among elites and the general public, the EU is primarily perceived as an economic player, while its role as a political power takes second place. While the pro-governmental Rossiyskaya Gazeta and Channel 
One picture the EU as a cynical actor hiding behind rhetorical statements, the elites perceive a more normative dimension of the EU. To many elite representatives, the EU's social problems are caused by excessive tolerance and soft power. The prerogative is to maintain national sovereignty; hence, national sovereignty is allowed to prevail over democratic values and moral ideals. The EU's inability to formulate a common position in regard to its internal problems makes the EU a difficult partner for Russia. Second, the EU's claim to moral superiority, its legitimate right and historic responsibility to promote "universal" values are, in fact, regarded by some interviewees as nothing more than a mask from behind of which to pursue its politico-economic interests and to dominate Russia's neighbours. Russian elites are sceptical about the EU's desire to promote democracy in the region, but this scepticism is not aggressive or sarcastic. The pro-government media do not believe in the legitimate right of the EU to promote "normative power." They do not consider the possibility that instruments other than military power can be used to realise politico-economic goals. The economic and English-language newspapers express normative content against the background of fairly traditional power-political interactions with the EU-the European supranational entity's principles and institutional arrangements can be ensured only through military capacities and control.

Finally, what can we say about the perceptions of efficiency of the EU actions on the space of Russia's "near abroad" and "far abroad"? Russia's perception of the EU reflects the realist paradigm of interests and hard power capacities. First, an effective and good political system equates to the ability to solve problems. The Russian media, together with some elite representatives, liken effectiveness to the term 'problem-solving capacity'. An ability to manage conflicts is based on institutional "capital" and legitimacy, as well as on military capacity. Military might is the most explicit manifestation of the great power status. Second, the perception of the aspect of the EU's effectiveness depends on the features of Russia's political order, public discourse, collective identity, non-rational beliefs, etc. The fact that the EU does not have a military force contributes to Russia's desire to be seen as a strong power. Evaluation and acceptance of political system and governance of the Other is part of self-image. The Russian pro-governmental media is not capable of clearly characterising Russia's distinct political system, but is very ready to criticise the EU's system of governance. What at first glance appears to be the EU's problem may well also be one of Russia's domestic challenges. This is particularly apparent in criticisms of the EU's asylum and immigration policy. Russia's own policies are also inefficient and demonstrate ineffective management. Notably, once the EU achieved a more coherent position toward the Arab Spring events or the Eastern enlargement, 
Russian media shifted rapidly to criticise the way the EU was managing the asylum flow or highlight the disadvantages of being an EU Member State. In other words, the media shifted its framing to report from the angle where the EU's weaknesses could best be depicted. The general public consider the EU as a unity and its external and internal actions as highly influential, although the efficiency of the EU is questioned. The elites express "peaceful scepticism" about the EU, the EU's limited achievements in the world arena are considered as a consequence of its limited capacity to use force. Third, the images of the Self and the Other "ha[ve] given rise to diverging interpretations of crucial foreign policy principles and objectives" (Gerrits, 2008, p. 8). As Kagan (2008, p. 19) notes, "Russia and the EU are neighbours geographically. But geopolitically they live in different centuries". Russia considers Western actions as provocations, while Western actors see themselves either as pursuing legitimate interests or as promoting democratic and human rights values. Misinterpretation of each other's actions is one of the reasons why Russia and the EU are uneasy partners.

\section{Conclusion}

The main aim of this article has been to contribute to a discussion about how nonEU countries characterise the EU. This research has incorporated three elements. As a starting point, the study addressed the question of how Russia interprets the EU's actions in the international arena. The first aspect of the study looked at the reflection on the EU in Russia's media; the second explored opinions towards the EU among political, business, social and media elites; the third discovered the public's views on the EU. This article contributes to the debate about what characterises the EU as a global power and at the same time enters into discussion of Russia's self-perception. In this respect it seems that what the Russian media, elites or general public consider as weakness and inefficiency is, in fact, a reflection of their self-belief about how the world is organised or should be organised. In addition, external opinions about the EU play a part in the EU's self-perception as a global power. While the EU considers itself to be an actor which applies "a comprehensive approach to crisis prevention and crisis management, [...] a rapid response capability" in order to "ensure continuing social cohesion and economic dynamism" (European Commission, 2003). Moscow considers the EU as an actor which should focus on its own problems. This study is a step toward diminishing the "communication problem" between Russia and the EU. 
Olga Gulyaeva is $\mathrm{PhD}$ candidate at the NCRE at the University of Canterbury, Christchurch, New Zealand. In 2009, Olga graduated from the Russian State Humanitarian University, Moscow, Russia, majoring in Cultural Studies. After completing her bachelor's with honours at the International Pacific College, Palmerston North, New Zealand, Olga was enrolled at the NCRE. Her PhD research is an integral part of the multi-national research project 'Image and Perceptions of the EU in Asia-Pacific', coordinated by Dr. Natalia Chaban and Prof. Martin Holland. Olga's thesis assesses how Russia's geographic location and historic background shape Russia's role in the Asian European Meeting (ASEM) and what are the images of the EU and its institutions: indeed, Russia's geopolitical positioning in the ASEM suggests that the EU is further cast into the role of Russia's major on the Eurasian continent. Olga's research interests are related to mass media reflection on political events.

\section{References}

Adomeit, H. (2011), Russia and its Neighbourhood: Competition and Conflict with the EU, Natolin Research Papers, no. 4. Retrieved from www.coleurope.eu/file/ content/studyprogrammes/eais/.../adomeit.pdf [accessed 26 May 2012]

Ashton, C. (2010), "The European Union's Role in Global Affairs," Hampton Road International Security Quarterly, 1 April 2010. Retrieved from http://search. proquest.com.ezproxy.canterbury.ac.nz/docview/215211075?accountid=14499 [accessed 25 Apr 2012]

Baranovsky, V. (2002), Russia's Attitudes Towards the EU: Political Aspects, Helsinki: Ulkopoliittinen Instituutti.

Bretherton, C. \& Vogler, J. (1999), The European Union as a Global Actor, London \& New York: Routledge. http://dx.doi.org/10.4324/9780203196076

Cerutti, F.(1992), 'Can there be a supranational identity?' Philosophy and Social Criticism, vol. 18, no. 2, pp. 147-162. http://dx.doi.org/10.1177/019145379201800204

Channel One Russia (2012), 'General Information,' Channel One Russia. Retrieved from http://www.1tv.ru/eng/total/ [accessed 20 Jun 2012]

Diez, T. \& Manners, I. (2007), 'Reflecting on normative power Europe,' in F. Berenskoetter \& M. J. Williams (eds.) Power in World Politics, London \& New York: Routledge, pp. 173-188.

Dulman, P. \& Fedyakina, A. (2011), Ukraina - osnovnaya dlya nas strana [Ukraine is the main country to us] Rossiyskaya Gazeta, no. 5501(125), 10 June 2011, p. 8.

Dunne, T. \& Schmidt, B. C. (2005), 'Realism,' in J. Baylis \& S. Smith (eds.) The Globalization of World Politics: an Introduction to International Relations, Oxford: Oxford University Press.

EUobserver.com (2011), 'EU foreign policy must not become a casualty of the euro crisis,' EUobserver. Retrieved from http://euobserver.com/opinion/114664 [accessed 14 Oct 2013] 
European Commission (2003), Communication from the Commission to the Council and the European Parliament Wider Europe - Neighbourhood: a New Framework for Relations with Our Eastern and Southern Neighbours, COM(2003) 104 final. Retrieved from http://ec.Europa.eu/world/enp/pdf/com03_104_en.pdf [accessed 21 Apr 2012]

European Union (2012), 'Consolidated Version of the Treaty of the European Union,' Official Journal of the European Communities, C325/5, p. 9.

Fischer, S. (2010), 'The EU, Russia and the Neighbourhood,' ISS Analysis, European Union Institute for Security Studies, 6 December 2010. Retrieved from http:// www.iss.Europa.eu/uploads/media/The_EU_Russia_and_the_neighbourhood.pdf [accessed 25 May 2012]

Fioramonti, L. \& Lucarelli, S. (2008), 'How do the Others see us? European political identity and the external image of the EU,' in F. Cerutti \& S. Lucarelli (eds.) The Search for a European Identity: Values, policies and legitimacy of the European Union, London: Routledge, pp. 193-210.

Fossato, F. (2006), Vladimir Putin and the Russian Television "Family", Paris: CERI Sciences Po, pp. 2-15.

Garcea, E. A. A. (2001), 'How Europeans perceive Europe: a case study from Italy,' European Business Review, vol. 13, no. 5, pp. 263-268. http://dx.doi.org/10.1108/ EUM0000000005794

Gerrits, A. (2008), 'The European Union and the Russian Federation: Dealing with the 'Grand Other' in A. Gerrits et al. (eds.) The European Union and Russia: Perceptions and Interest in the Shaping of Relations, The Hague: Clingendael Institute, pp. 5-14.

Gibson, J. J. (1959), 'Perception as a Function of Stimulation,' in S. Koch (ed.) Psychology: a Study of a Science, New York: McGraw-Hill, pp. 456-501.

Gomart, T. (2008), EU-Russia Relations: Toward a Way out of Depression, Paris \& Brussels: CSIS \& IFRI. Retrieved from http://www.ifri.org/files/Russie/Gomart EU_Russia.pdf [accessed 25 Apr 2011]

Greenhill, B. (2008), 'Recognition and collective identity formation in international politics,' European Journal of International Relations, vol. 14, no. 2, pp. 343-368. http://dx.doi.org/10.1177/1354066108089246

Helén, H. (2010), “The EU's Energy Security Dilemma with Russia,” POLIS Journal, vol. 4. Retrieved from http://www.polis.leeds.ac.uk/assets/files/students/studentjournal/ma-winter-10/helen-e.pdf [accessed 24 Jun 2012]

IDEA (2009), Democracy in development: global consultations on the EU's role in democracy building, Stockholm: International IDEA. Retrieved from www.idea. int/.../democracy_in_development/.../democracy_in_development-part_5.pdf [accessed 24 Oct 2010] 
Kagan, R. (2008), The Return of History and the End of Dreams, New York: Alfred A. Knopf.

Leonard, M. \& Popescu, N. (2007), 'A Power Audit of EU-Russia Relations,' London: European Council on Foreign Relations.

Light, M. (2008), 'Keynote Article: Russia and the EU. Strategic Partners or Strategic Rivals?' JCMS: Journal of Common Market Studies, vol. 46, pp. 7-27. http:// dx.doi.org/10.1111/j.1468-5965.2008.00808.x

Lomagin, N. A. (2008), 'Russian Perception of Europe and Its Implication for the Russia-EU Relations,' World Journal of Management and Economics, vol. 2, no. 1, pp. 36-40.

Mills, C. W. (1959), The Power Elite, Oxford \& New York: Oxford University Press.

Mir, M. J.; Dato, J. R. \& Garcia, R. V. (2010), 'The Perception of the European Union by Political and Economic Elites in Spain,' South European Society and Politics, vol. 15, no. 1, pp. 35-56. http://dx.doi.org/10.1080/13608746.2010.496923

Morini, M.; Peruzzi, R. \& Poletti, A. (2010), 'Eastern giants: The EU in the eyes of Russia and China,' in S. Lucarelli \& L. Fioramonti (eds.) External Perceptions of the European Union as a Global Actor, New York: Routledge, pp. 32-51.

Neumann, I. B. (1996), Russia and the Idea of Europe: A study in identity and international relations, London: Routledge. http://dx.doi.org/10.4324/9780203428566

Nice, A. (2012), Playing Both Sides: Belarus between Russia and the EU, DGAPAnalyse, no. 2 (March). Retrieved from https://dgap.org/en/article/getFullPDF/20847 [accessed 25 May 2012]

Pankov, V. (2008), 'Option for the EU-Russia Strategic Partnership Agreement,' Russia in Global Affairs, vol. 6, no. 2, pp. 172-184.

Pop, V. (2011), "EU Expanding its 'Sphere of Influence', Russia Says," EUobserver, 21 March 2009. Retrieved from http://euobserver.com/24/27827 [accessed 28 Jun 2011]

Rossiyskaya Gazeta (2011), 'About the newspaper,' Rossiyskaya Gazeta. Retrieved from http://www.rg.ru/about.html [accessed 5 Nov 2011]

Secrieru, S. (2010), Russia's Mainstream Perceptions of the EU and its Member States, SPES Policy Papers. Retrieved from www.iep-berlin.de/.../SPES_Policy_ Papers_2010_Secrieru.pdf [accessed 24 May 2012]

Smith, M. A. (2007), 'A Review of Russian Foreign Policy,' Conflict Studies Research Centre Russian Series, no. 07/20. Retrieved from www.da.mod.uk/colleges/arag/ document.../russian/07(20)MAS.pdf [accessed 28 Jun 2012]

Soshin, D. (2011), 'Evropeiskie lidery priznali krakh politiki multikulturalizma i pokaznoy politkorrektnosti,' [European leaders have admitted the failure of the policy of multiculturalism and sham political correctness] Channel One Russia. Retrieved from http://www.1tv.ru/news/world/170788 [accessed 25 Apr 2012] 
Statham, P. (2006), 'Political Journalism and Europeanization: Pressing Europe?' European Political Communication Working Paper, no. 13/06. Retrieved from http://www.eurpolcom.eu/exhibits/paper_13.pdf [accessed 5 Jun 2012]

Svanidze, N. (2011), Interview with N. Svanidze. Interviewed by Olga Gulyaeva, 20 December 2011, Moscow, Russia.

The Moscow Times (2009), The Only English Language Daily Business Newspaper in Russia. Retrieved from http://www.themoscowtimes.com/free_pdf/Media_Kit_ TMT_2009_eng.pdf [accessed 13 Dec 2012]

Toje, A. (2011), 'The European Union as a Small Power,' JCMS: Journal of Common Market Studies, vol. 49, no. 1, pp. 43-60. http://dx.doi.org/10.1111/j.14685965.2010.02128.x

Vedomosti (n.d.), 'Missiya' [Mission], Vedomosti. Retrieved from http://www.vedomosti. $\mathrm{ru} /$ about/mission.shtml [accessed 6 Nov 2011]

Vorobiyov, V. (2011), 'Ot svobody svobody ishchut,' [Seeking freedom from freedom] Rossiyskaya Gazeta, no. 407 (31), 15 February 2011, p. 8.

Waltz, K. N. (1979), Theory of International Politics, Reading, MA: Addison-Wesley.

Yeric, J. L. \& Todd, J. R. (1983), Public Opinion: The Visible Politics, Illinois: F. E. Peacock Publishers. 